\title{
Analysis of the Influence of Infrastructure on Economic Growth in North Sumatra Province
}

\author{
Syamsidar Sinaga ${ }^{1}$ Irsad $^{2}$, Rahmanta $^{3}$ \\ ${ }^{1}$ Postgraduate Students, Faculty of Economics and Business, Department of Economics, Universitas Sumatera \\ Utara, Indonesia \\ ${ }^{2,3}$ Postgraduate Lecturer, Faculty of Economics and Business, Department of Economics, Universitas Sumatera \\ Utara, Indonesia
}

Corresponding Author: Syamsidar Sinaga

\begin{abstract}
The objective of the research was to analyze the influence of road infrastructure, health infrastructure, and government spending in infrastructure on economic growth in North Sumatra Province. In the model equation, economic growth is dependent variable while road infrastructure, health infrastructure and government spending in infrastructure are independent variable. The scope of this research is the district and city in North Sumatra Province, exactly 32 districts/cities from 20152019. The analyzing model is the Fixed Effect Model, by using E-views 10 software. The result of the research showed that road infrastructure, health infrastructure, and government spending in infrastructure simultaneously had significant influence on economic growth. Partially road infrastructure had negative and not significant influence on economic growth, health infrastructure had positive and significant influence on economic growth and government spending in infrastructure had positive and not significant influence on economic growth in North Sumatra Province.
\end{abstract}

Keywords: Road Infrastructure, Health Infrastructure, Government Spending in Infrastructure, Economic Growth.

\section{INTRODUCTION}

The economy is said to grow or evolve if there is growth of real output. Growth occurs when there is a rise in output per capita. Economic growth illustrates the rise in the standard of living measured by real output per person. While the countrypoor country with a dense population and a lot of life at the level of the limit of life experiences the difficulty of raising it. Causes of low income in developing countries is the entry into force of the law of the addition result of the diminishing due to increasing population very quickly, while there is no power to encourage the growth of the economy in the form of increasing the quantity and quality of natural resources, capital, and technological progress (Naf'an in Ms Yanti et al, 2019:73).

Indonesia is one of the developing countries where the country of Indonesia doing a lot of development to improve the welfare of society. The construction is the basis for improving the welfare of the community. One of the indicators to see the development is economic growth. The positive economic growth indicates the presence of increased economic activity, on the contrary, negative economic growth showed a decline in economic activity (Maqin, 2011:10).

In the science of economic growth (economic growth) is the process of changes in economic conditions of a country continuously toward a better state for a certain period. Economic growth can be defined also as the process of increasing the production capacity of an economy which is manifested in the form of increase in national income (Hidayah et al, 2018:586). 


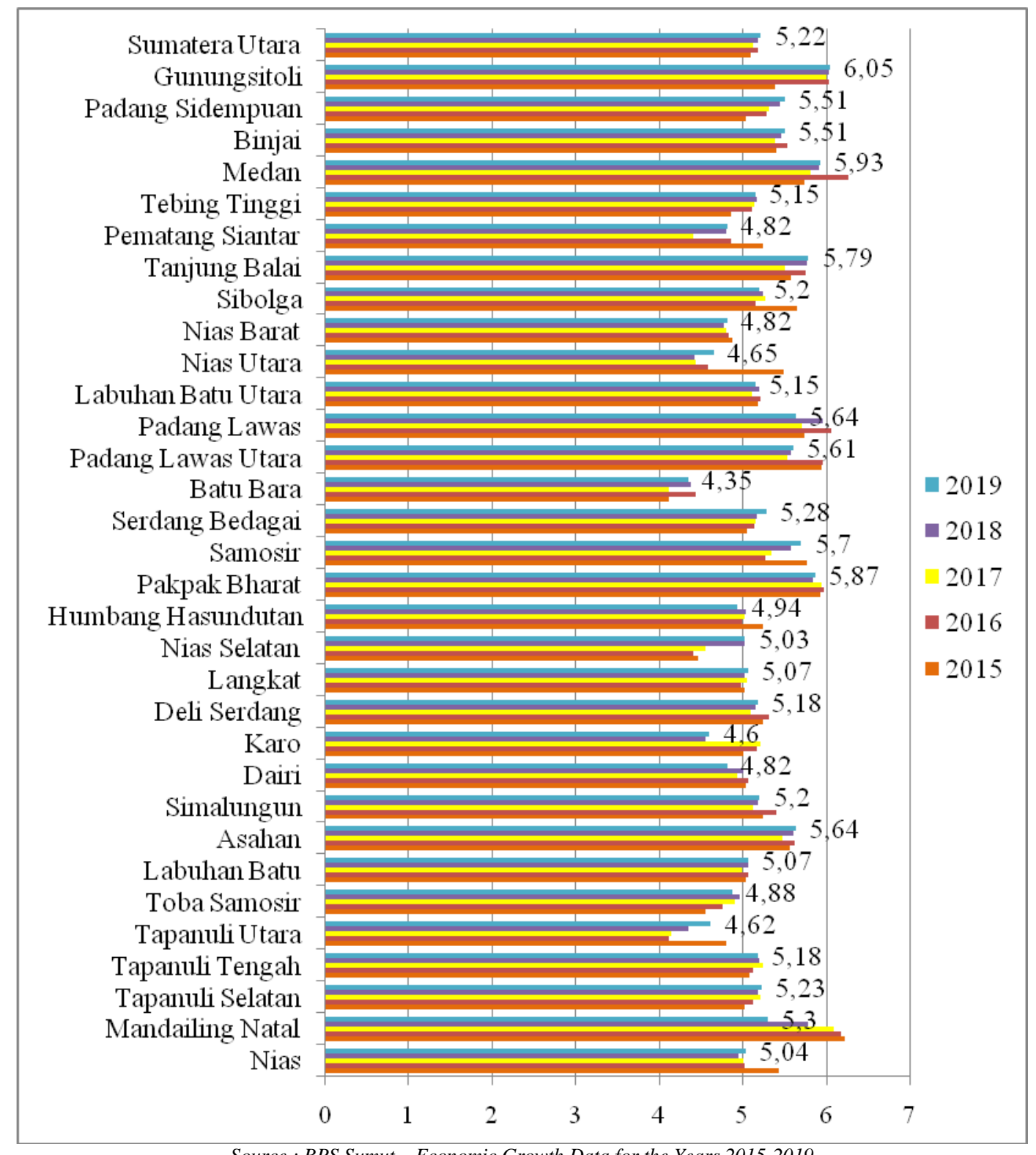

Source : BPS Sumut-Economic Growth Data for the Years 2015-2019

Chart 1.1 Economic Growth In North Sumatra Province On The Basis Of HargaKonstan Years 2015-2019 (Percent)

Chart 1.1 shows the growth of the economy of North Sumatra in years 20152018 fluctuated and increased from the year 2018-2019. The highest economic growth is the year 2019 of $5.22 \%$ and the lowest of the year 2015 amounted to $5,10 \%$. In the year 2016 economic growth in North Sumatra Province increased to $5,18 \%$, but in 2017 decreased to at 5.12\%. In 2018, economic growth in North Sumatra Province increased to 5,18\% and in 2019 back increased to $5,22 \%$.

Based on the district/city, in the year of 2015 the highest economic growth is a District Mandaling Christmas by 6,22\% and the lowest is Coal District of $4,11 \%$. In 2016, the highest economic growth is the City of Medan by 6,27\% and the lowest is North Tapanuli Regency amounted were 4.12\%. In 2017 the highest economic growth is a District Mandaling Christmas by $6,09 \%$ and the lowest is the Coal District of $4,11 \%$. In 2018, the highest economic growth is a Regency Gunungsitoli of $6.03 \%$ and the lowest is North Tapanuli Regency to $4.35 \%$. In the year 2019 the highest economic growth is a Regency Gunungsitoli by $6,05 \%$ and the lowest is Coal District to $4.35 \%$. The disparity in economic growth between the districts of the city are still 
visible. Overall, economic growth in North Sumatra is still supported 3 districts/cities, namely the City of Medan, Mandailing Natal Regency and Regency Gunungsitoli.

Donations quantity of GDP that fluctuate essentially determined by the magnitude of the contribution to the economy each district/city. The economic conditions of each district in the scope of time that can be identified based on the rate of growth by comparing the GDP in different years (years 2015-2019). The development of economic growth in North
Sumatra Province is influenced by several factors of infrastructure such as road infrastructure, and infrastrukturkesehatan. The policy of infrastructure development should be pursued in order to not only focus on increasing the value of output, but also on the evenness of its distribution. In the report on the year 2019, the World Economic Forum (WEF) revealed that the level of competitiveness of Indonesia still lags behind that of some countries. This can be seen on the Chart 1.2.

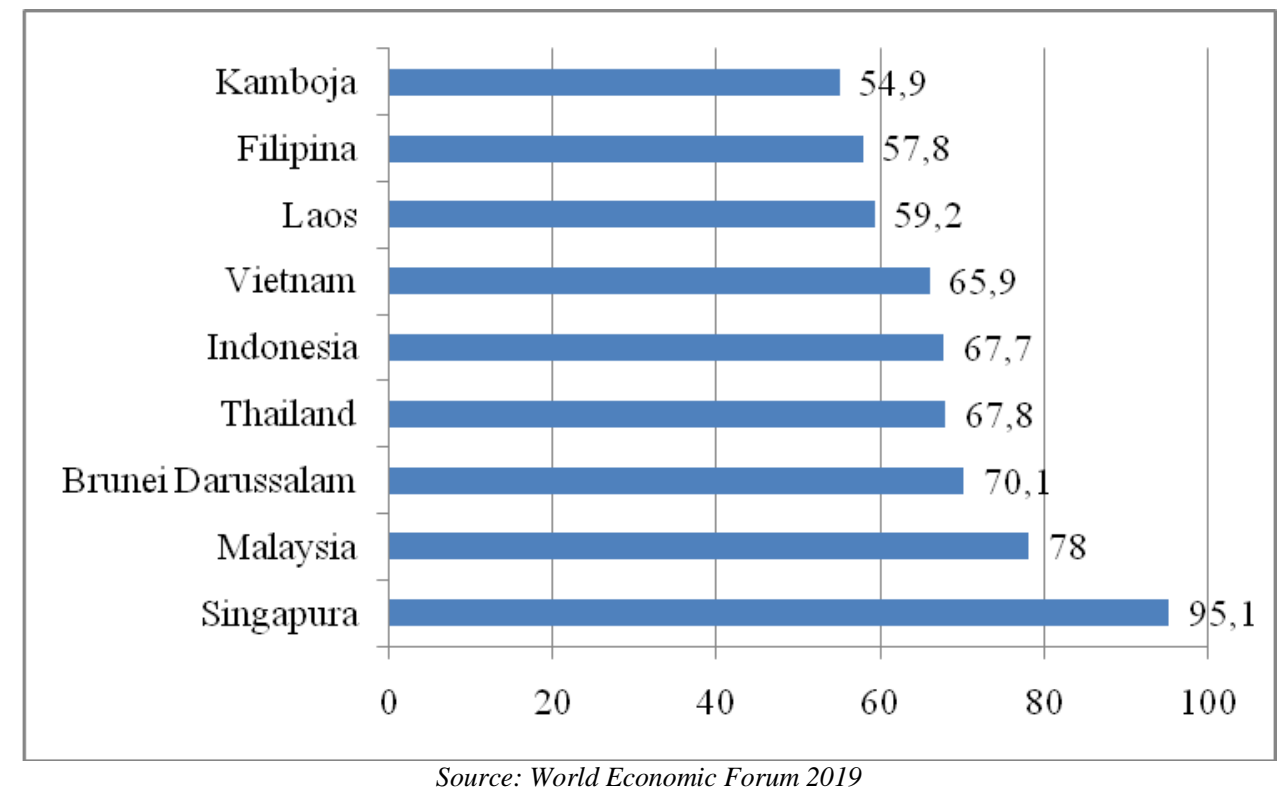

Chart 1.2 Infrastructure Competitiveness of ASEAN Countries in 2019

Chart 1.2 shows that the ranking of the competitiveness of Indonesia's infrastructure is still lagging behind in the area of Southeast Asia (ASEAN). Score Indonesia's competitiveness at the level to 67.7 points from a scale of $0-100$. These achievements make Indonesia is ranked 72 out of 141 countries surveyed and the fifth order in the ASEAN region. While Singapore remained in the rank of major as a country with infrastructure competitiveness of the highest in ASEAN with the score 95,1 .

The construction of the infrastructure is one of the important and vital part to speed up the process of national and regional development. Infrastructure also plays an important role as one of the drivers of the economic growth. The rate of economic growth of a country or region can not be separated from the availability of infrastructure such as transportation, energy and sanitation. This is what causes the development of infrastructure to be the foundation of sustainable economic development. Increasing infrastructure and its improvement by the government is expected to spur economic growth (Suratno in Sumadiasa et al, 2016:927).

Road infrastructure is required by each area. The road is the physical infrastructure, serves to connect the region with other regions and a variety of center activities, social and economic. The availability of road infrastructure in the Province of North Sumatra has an influence 
on economic growth, such as increasing the amount of output produced, the availability of employment opportunities, as well as the development of the sectors of the economy which will ultimately affect economic growth in a region.

Based on data obtained from BPS of road infrastructure in each district/city that is the path length of provincial and district roads shows the numbers that is different. More clear about the development of road infrastructure in North Sumatra can be seen in Chart 1.3.

Sumatera Utara 2019 seen from the quantity

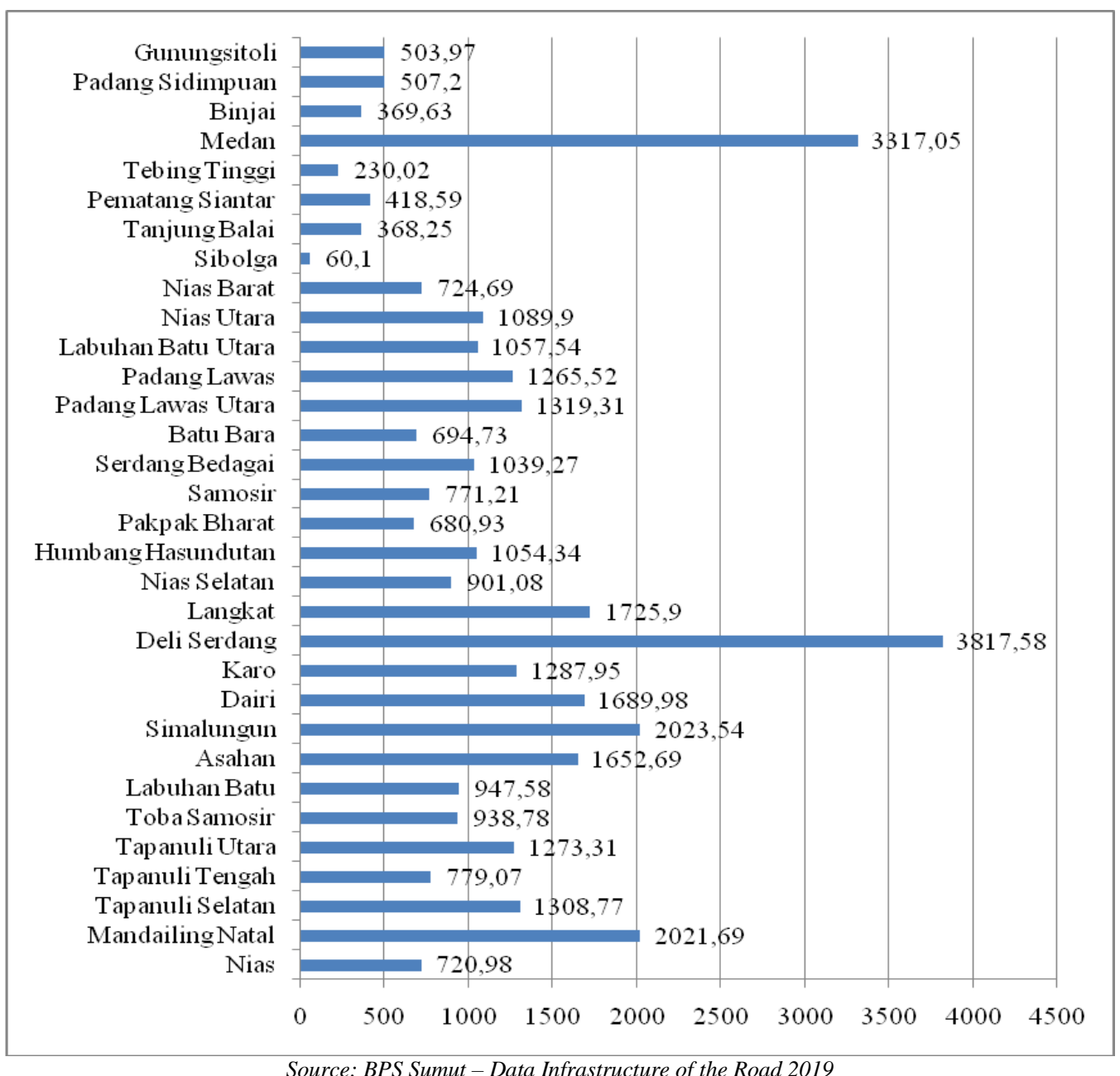

Chart 1.3 Road Infrastructure According to the Status of Province and District $(\mathrm{Km})$ in the Province of Sumatera Utara 2019

Chart 1.3 shows the total length of the roads of North Sumatra in 2019 is $36.561,2 \mathrm{~km}$. Based on the district/city, the infrastructure of the longest path is Deli Serdang Regency ie $3.817,58 \mathrm{~km}$ and the lowest is Regency, Sibolga, namely to 60.1 $\mathrm{km}$. The condition of the path length of low is very alarming because it will bring a negative impact to the whole society such as increasing the number of people who are isolated and reduce the investment into the Province of North Sumatra that will eventually affect the economic growth of
North Sumatra. Contribution of the business sector in the field of transport of 2019 have increased. Should be with the increasing contribution of the business sector in the field of infrastructure to economic growth, increase the amount and maintenance of road infrastructure. Whereas road construction and repair of roads in north Sumatra potentially improve the economy of $0.45 \%$ per annum above the baseline and extend the absorption of labor by $0.15 \%$. Increasing the efficiency of the economy as a result of good road infrastructure also 
encourages an increase in exports of $0.75 \%$ per year.

In addition to road infrastructure, health is also an important capital for the conduct of economic activity, where the healthy person it can improve productivity in the work. The existence of a health facility may be an option for people who have health complaints for treatment. Health infrastructure has an influence on economic growth. Health infrastructure is able to provide a qualified workforce to economic growth. Based on data obtained from BPS Sumatera Utara 2019 seen from the quantity of health infrastructure in each district/city that the number of hospitals, puksesmas and health centers maid shows numbers that is different. More clear about the development of the health infrastructure in North Sumatra can be seen in Chart 1.4.

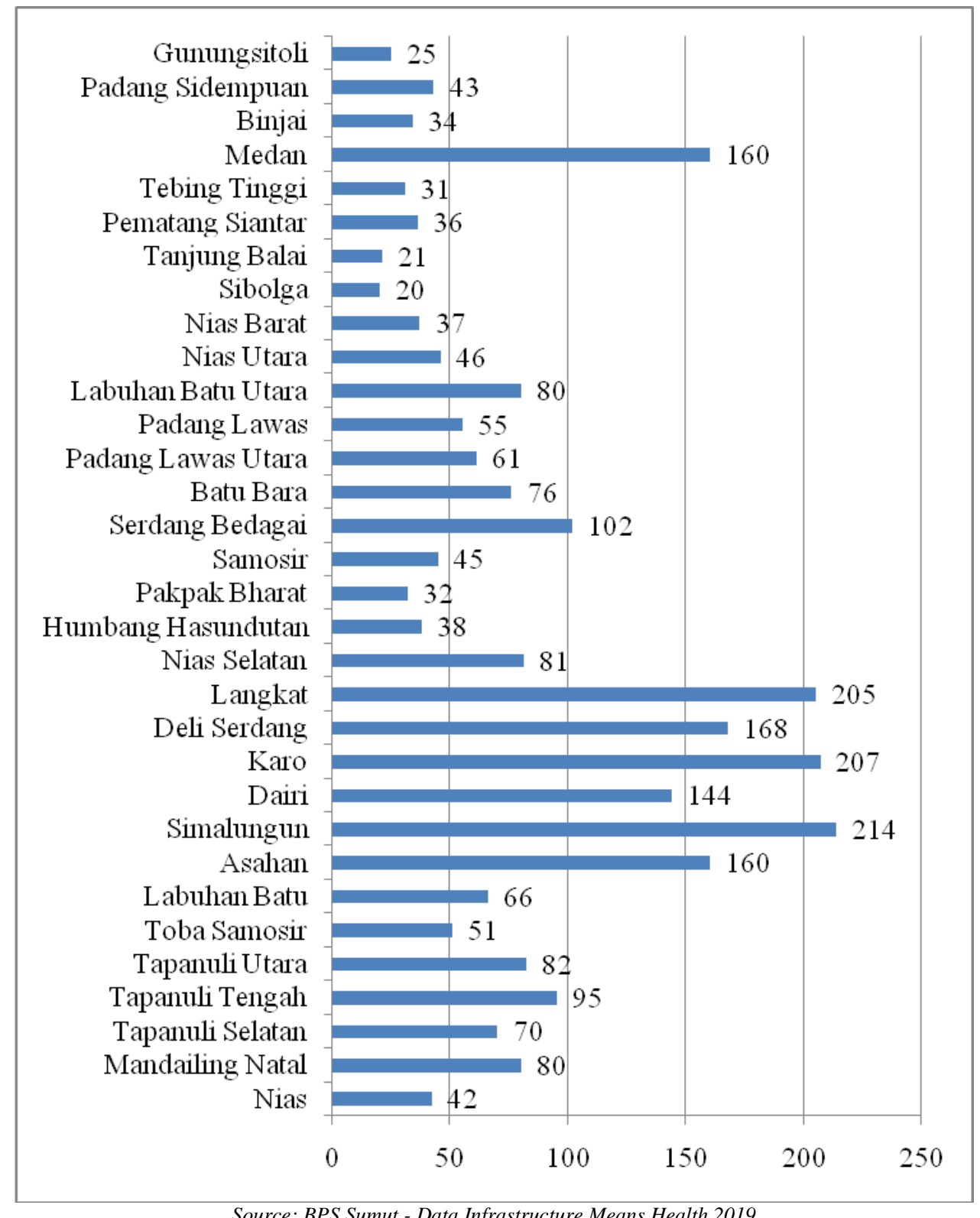

Chart 1.4 Health Infrastructure According to the Number of Health Facilities (Units) in the Province of Sumatera Utara 2019

Chart 1.4 shows the number of health facilities of the Province of North Sumatra in the year 20192607 unit. Based on the district/city health facilities the most is Simalungun 214 the unit followed with Karo and the lowest is the city of Sibolga as many as 20 units followed the City of Tanjung Balai as much as 21 units. 
The development of the number of health facilities as much as 22 districts/cities have not yet reached the average number of health facilities of North Sumatra. Funds allocation of health budgeted as much as $10 \%$ in the Budget of the Regional budget (APBD) is not sufficient only 2-4\% (RKPD north Sumatra 2017:15). While the contribution of the business sector in the field of health the 2019 rose. The availability of a number of means limited health will have an impact on the decrease in the degree of health of the Province of North Sumatra.

In support of the government's infrastructure development policy through government spending. Government spending plays a role in the formation of capital through government spending in areas such as facilities and infrastructure. Capital formation in infrastructure and generally be social overhead capitalyang very important in the economic growth. Social overhead capital is very important because the parties would not be willing to provide the various facilities to the public, but in the absence of public facilities is then the private sector is not interested to invest (Adeyo et al, 2019:212). Efforts to encourage economic growth through the improvement and development of infrastructure with the expenditure of infrastructure budget was directed to melaksanakanprogram priorities such as program management, road, and water resources (Nuritasari, 2013:459).

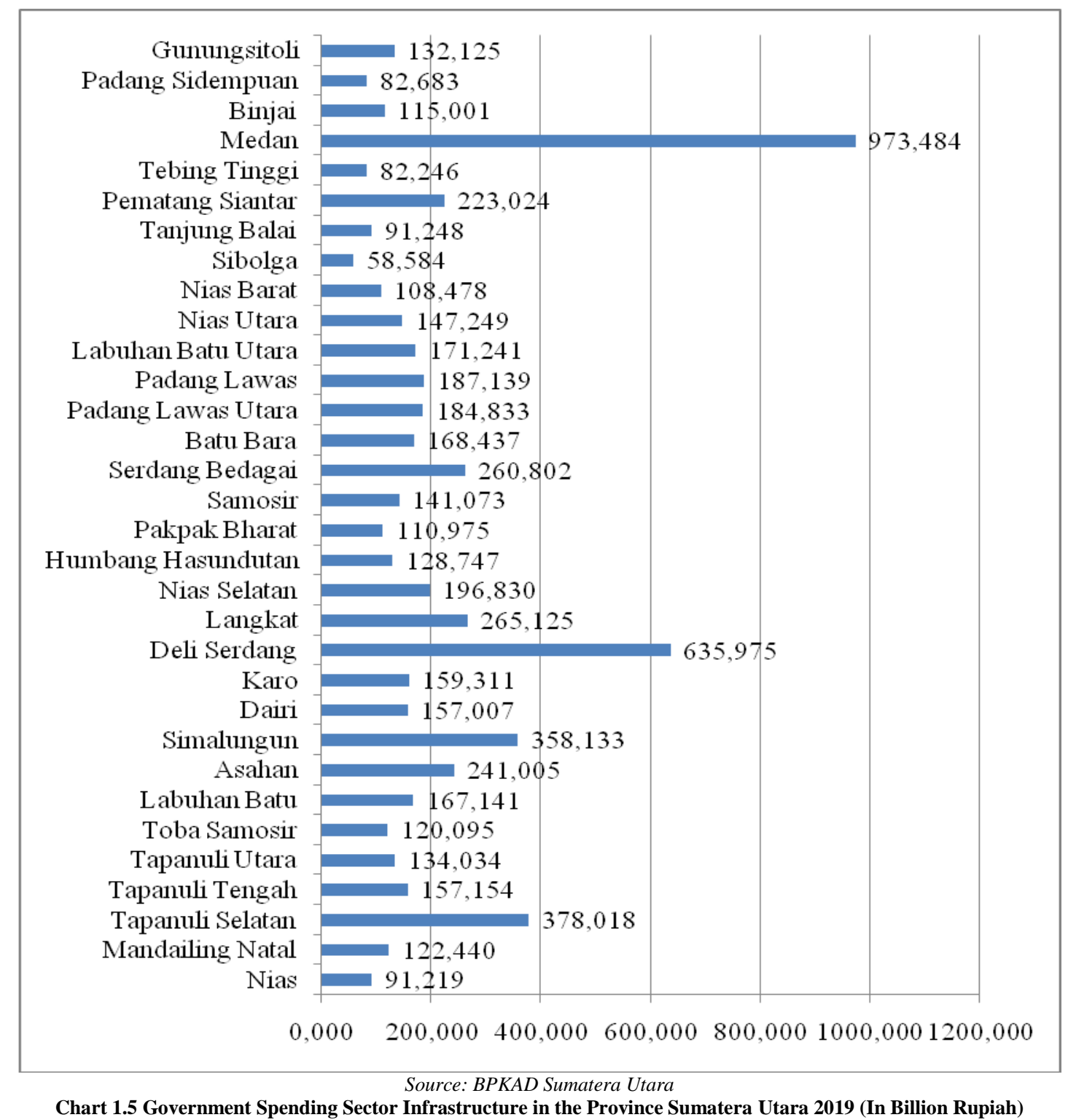


Chart 1.5 shows the expenditure of the government sector infrastructure in North Sumatra Province of 2019 amounted to 6.5 trillion rupiah. Based on the district/city, in 2019 the government spending sector infrastructure is the largest City of Medan, namely 973,4 billion dollars, while the look of the provision of infrastructure 2019 long way the largest of the year 2019 is Serdang and the number of health facilities is the largest Simalungun. Then the government spending sector is the infrastructure of the lowest of the year 2019 is Sibolga City of 58.5 billion rupiah. Based on the Theory of Musgrave (Ladung, 2018:21) states the expenditure of the government for the public sector is elastic to economic growth. More and more government spending for the public sector, more public goods that are available to the public.

Previous researchers who discuss about the influence of infrastructure to economic growth to obtain the results to vary. In a study conducted by Pranessyet al (2012:1) explains that the length of the path, the sale of electric energy, clean water, the number of health centers and the number of schools has positive and significant effect on economic growth in the Province of Bengkulu. Another study conducted Maqin (2011:10) shows that the electricity infrastructure, labor, and development expenditure has a positive and significant influence on economic growth. For road infrastructure and educational infrastructure has a positive relationship but not significant. While the health infrastructure have a relationship that is negative and not significant.

The development of infrastructure in the Province of North Sumatra has lasted long enough and with a considerable cost as well as a significant contribution towards the improvement of economic growth. However there are still many problems faced by the Province of North Sumatra, among others, the management of the funds that less evenly the quality of the infrastructure is still low, the deployment infrastructure that is not evenly, care inadequate infrastructure and so on.

\section{LITERATURE REVIEW Economic Growth}

Economic growth is the process of increase in output per capita in the long term. The emphasis on the process, because the process contains elements of dynamic (Boediono in Tarmizi, 2013:19). The theoretical science of economic development stated that economic growth is not just measured by the increase of the Gross Domestic Product and Gross Regional Domestic Product, but also given a weight that is immaterial such as enjoyment, satisfaction and happiness with a sense of security and peace that is felt by the wider community.

\section{Infrastructure}

Infrastructure (infrastructure) according to Oxford Dictionaries (in Mulyoet al, 2018:1) is the physical structure and the basic organization such as buildings, roads, energy supply necessary for the operation of society and institutions.

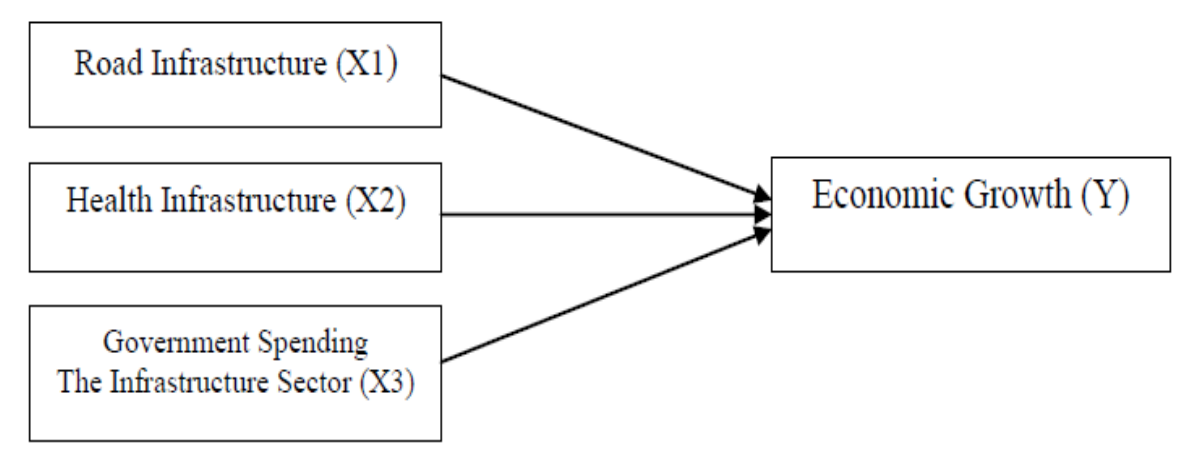

Figure 1. Conceptual Framework 


\section{Hypothesis}

1. Road infrastructure has a positive influence on economic growth in North Sumatra Province.

2. Health infrastructure has a positive influence on economic growth in North Sumatra Province.

3. Government spending sector infrastructure has a positive influence on economic growth in North Sumatra Province.

4. Road infrastructure, health infrastructure and government spending sector infrastructure simultaneously have pengaruhterhadap economic growth in the Province of North Sumatra.

\section{MATERIAL AND METHODS}

This research was conducted using quantitative approach. Quantitative research is a method in the research process and process the data in the form of numbers as a tool used to analyze and conduct research studies (Syriac and Hendrayadi, 2015:109). This study uses statistical data to analyze the influence between variables are examined to get a conclusion that applies in general.

The Data used in this research is secondary data with the analysis of panel data. The use of panel data in this study is caused by the limitations of time series data for each district. Panel Data used is the combined time series data (time series) of the year of 2015-2019 and the data slice cross (cross section) are taken from the 32 counties/city di the Province of North Sumatra obtained from related institutions, either in the form of statistical data or other written information.

Data collection method in this research is a study of the documentation, because in this case the researchers did not directly take itself but researching and collecting data, namely in the form of financial statements, the documents, published reports, records, and other information of internet site that are generated by other parties. These Data will be further processed in accordance with the needs of the researcher. The Data obtained from the official website which is published by the Central bureau of Statistics and the department of the Agency of Finance and Asset Management Areas.

\section{RESULTS AND DISCUSSION Analysis Of The Effect Of Road Infrastructure On Economic Growth}

Regression results in the value of the variable coefficients of road infrastructure by $-0,0002$ and the probability of 0,1282 because the probability is greater than 0.05 then the variable path has a negative effect not significant to the variable of economic growth. Neither the value of the regression coefficient $-0,0002$ which means that if the number of path length up to $1 \mathrm{~km}$, then the economic growth fell of 0.0002 percent. The results of the estimation of such models can be concluded that the road infrastructure in the Province of North Sumatra in the year 2015 to the year 2019 has a negative effect not significant to economic growth. It is not in accordance with the Theory of Solow stated that there are different types of capital, a privately-owned company investing in various forms of capital public that infrastructure such as roads, bridges and sewerage. It is certainly contrary to previous research which states that the road infrastructure can encourage the growth of the economy of a region.

This study together with previous research, namely: Hamzah, the Priest R. and Setiawan, Dedy (2019), the Influence of Infrastructure On Economic Growth in South Sumatra 2014-2017; Febriaty, Hastina (2018), the Influence of Road Infrastructure and the Power Deficit On the Economic growth of North Sumatra. Research shows that the road infrastructures have negative effect not significant to economic growth. But the results of this study contrast with the results of the research Keusuma, Cut Nanda (2015) who examined the about the Construction of Basic Infrastructure to the Growth of the Economy in Indonesia, shows that the road infrastructure have a positive and significant 
impact on economic growth in Indonesia. The difference in the results of this study allegedly because of differences in the location of research where the object of research conducted by Hamzah and Setiawan, Febriaty Hastina smaller which includes the province compared to the location of the research Keusuma wider which includes 26 Province in Indonesia.

As for the things that make the road infrastructure in the Province of Sumatera Utara not have an influence on economic growth, namely the condition of road infrastructure better each regency/city in North Sumatra Province from year 20152019 categorized decreased. In 2015 the road conditions are better that $13.612 \mathrm{~km}$, in 2016 the road conditions are better that $13.239 \mathrm{~km}$, in the year of 2017 is in good condition and that $12.610 \mathrm{~km}$, in the year of 2018 is in good condition and decreased back that $12.568 \mathrm{~km}$, but in the year 2019 good road conditions were little changed, namely $12.568 \mathrm{~km}$ (BPS). Based on the district/city, the area experienced a decline in good road conditions from year 20152019, namely Kabupaten Nias District Labuhan Batu Regency, Simalungun Regency, Nias Selatan, Pakpak Bharat, and North Nias Regency. Decline in good road conditions caused by the increase in the number of motor vehicles passing of the years 2015-2019 such as passenger cars, freight cars, car, bus and motorcycle. In 2015 the number of motor vehicles as much as 5.824.720 unit, 2016 as much as 6.798.265 units, 2017 as much as 7.094.015 units, 2018 as much as 7.781 .587 unit and the year 2019 8.097.163 unit. Furthermore, the repair is made gradually, so that the results are not optimal. In 2015, the Department of highways of the Province of North Sumatra can do the repair of the road a few miles, in the year 2016 repair roads other. At the time of workmanship of the roads in the next year, the path of the first fixed already suffered damage so that the roads have not been able to support the activities of the society.
The length of the road is no longer the only major supporter of the smoothness of the economy. This is due to each district already has road access, so it does not require the addition of a long road again. The quality of the move which further plays an important role to the smooth flow of economic inter-region-region economy. For example if the length of the road with good road conditions will make the distribution of goods ekonomilebih quickly sent because the risk of crash and the slow pace of the vehicle due to damaged roads will be smaller. On the contrary the length of the road with road conditions damaged will cause the risk of crash and delay in delivery is high. So at this time, although the growth of the length of the road tend to be slow, but if the quality of the jalansemakin improved the smoothness of economic goods and services will contribute greatly in favor of economic growth that is increasingly high.

\section{Analysis Of The Influence Of The Infrastructure Of Health On Economic Growth}

Regression results in the value of the coefficient of the variable of health infrastructure of 0.002 and the probability of 0,0244 because the probability is smaller than Alpha 0.05, then the variable health infrastructure has a positive and significant influence on economic growth. Neither the value of the regression coefficient 0.002 means that if the addition of infrastructure health increased by 1 unit, then the growth of the economic rise of 0.002 percent by the assumption of ceteris paribus. The results of the estimation of such models can be concluded that the health infrastructure in the Province of North Sumatra in the year of 2015 to 2019 have a positive and significant influence on economic growth.

The results of this study are in line with research conducted by Pane et al(2020) the Influence of the Construction of the Infrastructure of Health, Education and Population on Economic Growth in North Sumatra, Pranessy et al (2013) Effect of Infrastructure Development On Economic 
Growth in the Province of Bengkulu. The results of these studies show that the health infrastructure has positive and significant effect on economic growth.

Health infrastructure has positive and significant effect on economic growth due to the increasing health of the community will have an average live longer thus economically have the opportunity to earn higher incomes. In the year 2015-2019 in life expectancy in the Province of North Sumatra each year has increased. In 2015 the percentage of life expectancy that is $68,29 \%$, in 2016 the percentage of life expectancy that is $68,33 \%$, in 2017 the life expectancy that $68,37 \%$, in 2018 life expectancy that is $68,61 \%$ and in 2019 life expectancy that is $68,95 \%$ (BPS Sumut).

According to the World Health Organization (WHO) services in the health field can be realized through hospitals and community health centers and other health services. The development of health infrastructure, both in quantity and quality, will encourage the improvement of the quality of human resources. Health is one of the requirements for the human resources to perform an activity, especially activities of the economy. To support public health, the government provides health facilities that hospitals, health centers and health centers can provide health care to the community in the Province of North Sumatra. Health is a fundamental requirement for every human being, without public health can not produce a productivity for the region.

The economic activity of a country would be run if there is a guarantee health care for every population. Expected role of the government in providing the adequate health facilities, building health facilities that reach up to the corner of the village, able to build health centers and pukesmas maid so that every people can get health care that is easily accessible and low cost. The health facilities are available and affordable will determine the success of the development of the health sector. Where the construction of the health impact on the condition of human resources so that the quality of human resources that will improve the productivity of the economy in their respective regions.

\section{Analysis Of The Influence Of Government Spending Sector Of Infrastructure On Economic Growth}

Regression results in the value of the coefficient of the variable of health infrastructure by 0,000019 and the probability of 0,9540 because the probability is greater than the Alpha of 0.05 then the variable expenses of the government sector infrastructure has a positive effect not significant to economic growth. Neither the value of the regression coefficient 0,000019 which means that if the addition of the expenditure of the government infrastructure sector rose by 1 billion dollars, then economic growth rose 0,000019 percent with the assumption of ceteris paribus. The results of the estimation of such models can be concluded that the government spending sector infrastructure in the Province of North Sumatra in the year 2015 to the year 2019 has a positive effect not significant to economic growth.

This is according to the Theory of Wagner which states that if government spending increases, per capita income is relatively increased. Government spending the infrastructure sector has no significant effect on economic growth, this is due to infrastructure development budget of the Province of North Sumatra focus only on some areas only. The realization of government spending sector infrastructure remains increased but uneven development raises the disparities that can slow down economic growth, while the GDP of the Province of North Sumatra is not only from the several districts/cities only. In the year 2015-2019 in government spending sector infrastructure focus on some of the district/city, namely the City of Medan, Langkat Regency and Deli Serdang Regency while the government spending sector infrastructure for the City of Sibolga, Distric Pakpak Bharat and the City of 
Padang Sidempuan from year 2015-2019 very low (BPS).

The results of this study in accordance with the research conducted by Windu's Son (2018) the Impact of Government Spending On Economic Growth and Human Development Index on the Border of Indonesia; Ladung, Dawn (2018) Analysis of the Effect of Government Spending on Education, Health and Infrastructure On Economic Growth in the City of Pare-Pare. The results of the study show that the government spending sector infrastructure have a positive and significant impact on economic growth.

Infrastructure is the physical system that are needed to meet basic human needs in the social sphere and the economy. With the maintenance of existing infrastructure in an area will certainly facilitate trade and the economy, improve the quality of human resources through health and will encourage the investors to invest. More and more government spending for maintenance and the provision of public goods, the quality of public goods that are perceived by the society, such as the maintenance of road infrastructure, health infrastructure and so on. It can be seen from the fact that the area which has the complete infrastructure system that is better, have a higher rate of economic growth and the welfare of the community, which is better anyway, compared to the area that has the complete infrastructure is limited. With an increase in the government spending sector infrastructure is expected to give attention to the increase of public investment so that infrastructure needs can be met and can increase economic growth

\section{CONCLUSIONS AND RECOMMENDATIONS CONCLUSIONS}

Based on the results of the analysis and discussion of the conclusions that can be drawn from the study is as follows:

1. Road infrastructures have a negative influence on economic growth in North Sumatra Province of years 2015-2019.
The road infrastructure in the Province of Sumatera Utara not have an influence on economic growth because kondisijalan good each regency/city in North Sumatra Province from year 2015-2019 categorized decreased.

2. Health infrastructure has a positive and significant influence on economic growth in North Sumatra Province of years 2015-2019.

3. Government spending sector infrastructure has a positive effect not significant to economic growth in North Sumatra Province of years 2015-2019.

4. Road infrastructure, health infrastructure and government spending sector infrastructure simultaneously significant effect on economic growth in North Sumatra Province of years 2015-2019.

\section{RECOMMENDATIONS}

Suggestions of researchers from the research that has been done is as follows:

1. The North Sumatra Provincial government need to open wide project management unit to private investment, especially investment in the country in the field of road infrastructure. Increased repair of damaged roads need to be done to improve the accessibility and productivity of the community.

2. Government district in North Sumatra Province need to encourage development in the field of health infrastructure because it can give you a multiplier effect that is significant to the community of North Sumatra Province.

3. By considering the indicators of the government spending sector infrastructure, the government is expected more and more wise in using the budget function infrastructure so that infrastructure development is evenly distributed in every region of North Sumatra.

4. The availability of infrastructure is not yet fully evenly, so the expected to the public using the facilities and infrastructure available with the wise. 
5. The period in this study covers only for 5 years because of the limitations of the research data. For academics and students need to be held research that adds to the period of study is long again to determine the pattern of the influence of infrastructure and government spending sector infrastructure in the longer term.

\section{Acknowledgement: None}

\section{Conflict of Interest: None}

\section{Source of Funding: None}

\section{REFERENCES}

1. Amri, Khairul. 2014. Infrastruktur Transportasi dan Kepadatan Penduduk Terhadap Pendapatan Per Kapita: Panel Data Evidence dari Sembilan Provinsi di Sumatera. Jurnal Ekonomi dan Bisnis Volume 2 No 2, 2014. ISSN: 2338- 2929. https://www.researchgate.net/publication/33 5757302.

2. Arumsari, Roswalina Fega. Hutajulu, Dinar Melani. 2020. Analisis Pengaruh Pembangunan Infrastruktur Terhadap Pertumbuhan Ekonomi di Pulau Sulawesi Tahun 2014-2018. Jurnal Paradigma Multidisipliner Volume 1 No 1, 2020.

https://media.neliti.com/media/publications/ 319904-analisis-pengaruh pembangunaninfrastruk-33d230fb.pdf.

3. Atmaja, HarryKurniadi. Mahalli, Kasyful. 2015. Pengaruh Peningkatan Infrastruktur Terhadap Pertumbuhan Ekonomi di Kota Sibolga.Jurnal Ekonomi Volume 3 No 4, 2015.

https://jurnal.usu.ac.id/index.php/edk/article /view.

4. Badan Pusat Statistik Indonesia. 2016. Statistik Indonesia 2016.

5. Badan Pusat Statistik Indonesia. Statistik Infrastruktur 2014 dan 2019.

6. Badan Pusat Statistik Indonesia. 2016. Statistik Transportasi Indonesia 2016.

7. Badan Pusat Statistik Provinsi Sumatera Utara. Berita Resmi Statistik 20152019,Data Pertumbuhan Ekonomi Provinsi Sumatera Utara.

8. Badan Pusat Statistik Provinsi Sumatera Utara. Berita Resmi Statistik 2015-
2019,Data Infrastruktur Provinsi Sumatera Utara.

9. Cahyono, Eko Fajar. 2012. Analisis Pengaruh Infrastruktur Ekonomi TerhadapProduk Domestik Bruto di Indonesia. Jurnal Ekonomi Pembangunan Volume 10 No 2, 2012.

http://ejournal.umm.ac.id/index.php/jep/arti cle/view.

10. Effendi, Nury. Setiawan, Maman. 2014. Ekonometrika Pendekatan Teori dan Terapan. Jakarta: Salemba Empat.

11. Faradis, Royhan. Afifah, UswatunNurul. 2020. Indeks Komposit Pembangunan Infrastruktur Provinsi-Provinsi di Indonesia.Jurnal Ekonomi dan Pembangunan Indonesia Volume20 No 1, 2020. ISSN 1411-5212.

12. https://jepi.fe.ui.ac.id/index.php/JEPI/article /view.

13. Febriaty, Hastina. 2018. Pengaruh Infrastruktur Jalan dan Defisit Listrik Terhadap Pertumbuhan Ekonomi Sumatera Utara.Jurnal Riset Finansial Bisnis Volume 2 No 2, 2018. ISSN 2597-3991. https://ejurnal.id/index.php/jrfb/article/view.

14. Fikriah. Wulandari, Meta. 2015. Analisis Pengaruh Investasi Infrastruktur Publik Terhadap Pertumbuhan Ekonomi di Aceh. Jurnal Ekonomika dan kebijakan Publik Volume 2 No 1, 2015. ISSN 2442-7411. http://jurnal.unsyiah.ac.id/ekapi/article/dow nload.

15. Gujarati, Damodar N. Porter, Dawn C. 2003. Ekonometrika Dasar. Jakarta: Salemba Empat.

16. Gujarati, Damodar N. Porter, Dawn C. 2004. Ekonometrika Dasar.Jakarta: Salemba Empat.

17. Gujarati, Damodar N.Porter, Dawn C.2011. Dasar-Dasar Ekonometrika Buku1.Jakarta: Salemba Empat.

18. Gujarati, Damodar N. Porter, Dawn C. 2012. Dasar-Dasar Ekonometrika Buku 2 Edisi 5. Jakarta: Salemba Empat.

19. Hamzah, Imam Royani. Setiawan, Dedy. 2019. Pengaruh Infrastruktur Terhadap Pertumbuhan Ekonomi di Sumatera Selatan 2014-2017.Jurnal Ilmiah Indonesia Volume 4 No 10, 2019. ISSN 2541-1398.

Jurnal.syntaxliterate.co.id/index.php/syntaxliterate/article/view.

20. Hasyim, Ali Ibrahim. 2016. Ekonomi Makro. Depok: Kencana. 
21. Hidayah, Farik. Azha, Zul. Putri, DewiZaini. 2018. Analisis Kausalitas Pertumbuhan Ekonomi, Infrastruktur dan Penerimaan Pajak di Provinsi Sumatera Barat.EcoGen Volume 1 No 3, 2018. http://ejournal.unp.ac.id/students/index.php/ pek/article/view.

22. Jhingan, M. L. 2016. Ekonomi Pembangunan dan Perencanaan. Jakarta: Rajawali Pers.

23. Karya, Detri. Syamsudin, Syamri. 2016. Makro Ekonomi. Jakarta: Raja Grafindo Persada.

24. Keusuma, Cut Nanda dan Suriani. 2015. Pengaruh Pembangunan Infrastruktur DasarTerhadap Pertumbuhan Ekonomi di Indonesia.Jurnal Ilmiah Ekonomi dan Pembangunan Volume 4 No 1, 2015 ISSN 2302-8408.

http://ejournal.unp.ac.id/index.php/ekosains/ article/view.

25. Khusaini, Mohamad. 2019.Ekonomi Publik. Malang: UB Press.

26. Ladung, Fajar. 2018. Analisis Pengaruh Pengeluaran Pemerintah di Bidang Pendidikan, Kesehatan dan Infrastruktur Terhadap Pertumbuhan Ekonomi Kota Parepare. Jurnal Ekonomi dan Bisnis Volume 1 No 2, 2018. ISSN. 2615-7039. https://jurnalpertanianumpar.com/index.php/ economos/article/view.

27. Lestari, Mega. Suhadak. 2019. Pengaruh Pembangunan Infrastruktur TerhadapPertumbuhan Ekonomi dan Pemerataan Ekonomi Indonesia.Jurnal Administrasi Bisnis Volume 70 No 1, 2019.administrasibisnis.studentjournal.ub.ac .id.

28. Maqin, Abdul. 2011. Pengaruh Kondisi Infrastruktur Terhadap Pertumbuhan Ekonomi di Jawa Barat.Trikonomika Volume 10 No 1, 2011. ISSN 1411-514X. https://www.researchgate.net/publication/29 0196080_Pengaruh_Kondisi_Infrastruktur_t erhadap_Pertumbuhan_Ekonomi_di_Jawa_ Barat.

29. Ms, Yanti. Naidah, Badollahi Ismail. 2019. Pengaruh Infrastruktur Jalan, Listrikdan Air Terhadap Pertumbuhan Produk Domestik Regional Bruto di Kabupaten Gowa Provinsi Sulawesi Selatan.Jurnal Ekonomi Balance Fakultas Ekonomi dan Bisnis Volume 15 No 1, 2019. ISSN 1858-2192. https://journal.unismuh.ac.id/index.php/bala nce.
30. Mulyo, Sulistijo. Sidarto dan Santoso, Budi. 2018. Proyek Infrastruktur dan Sengketa Konstruksi. Depok: Prenada Group.

31. Nugroho. 2016. Analisis Pengaruh Pengeluaran Pemerintah Terhadap PertumbuhanEkonomi dan Indeks Pembangunan Manusia di Indonesia. Jurnal Perbendaharaan, Keuangan Negara dan Kebijakan Publik Volume 1 No 1, 2016. https://itrev.kemenkeu.go.id/index.php/ITRe v/article/view.

32. Nuritasari, Firdausi. 2013. Pengaruh Infrastruktur, PMDN dan PMA Terhadap Produk Domestik Bruto di Indonesia.Economics Development Analysis JournalVolume 2 No 4, 2013. ISSN 22526889.http://journal.unnes.ac.id/sju/index.ph p/edaj.

33. Pane, Ritonga.Sembiring, Sri Devi. Unsa, Ikhwani. 2020. PengaruhPembangunan Infrastruktur Kesehatan, Pendidikan dan Jumlah Penduduk Terhadap Pertumbuhan Ekonomi di Sumatera Utara.Jurnal Sekolah PGSD FIP Unimed Volume 4 No 2, 2020. ISSN 2548-8856. https://jurnal.unimed.ac.id/2012/index.php/j s/article/view.

34. Pranessy, Lise. Ridwan, $\mathrm{N}$ dan Merri, A. 2012. Pengaruh Pembangunan InfrastrukturTerhadap Pertumbuhan Ekonomi Provinsi Bengkulu.Jurnal Ekonomi dan Perencanaan Volume 4 No3, 2012. ISSN 1979-7338. http://repository.unib.ac.id/7631/1/JEPPVo L4N03Jan2012.pdf.

35. Pratama, Nengah Rai. Utama, Made Suyana. 2019. Pengaruh Pengeluaran Pemerintah dan Investasi Terhadap Pertumbuhan Ekonomi dan Tingkat Kemiskinan di Kabupaten/Kota Provinsi Bali.Jurnal Ekonomi dan Bisnis Volume 8, Nomor 7 ISSN 2337-3067. https://ojs.unud.ac.id/index.php/EEB/article/ view.

36. Putra, Windu. 2017. Dampak Pengeluaran Pemerintah Terhadap Pertumbuhan Ekonomi dan Indeks Pembangunan Manusia di Perbatasan Indonesia. Jurnal Ekonomi, Bisnis dan Kewirausahaan Volume 6 No 2, 2017.

https://core.ac.uk/download/pdf/194874166. pdf.

37. Rencana Kerja Pemerintah Daerah Provinsi Sumatera Utara Tahun 2017. 
https://www.sumutprov.go.id/images/Er201 7/Oktober/bab_I_Pendahuluan.pdf.

38. Ristiyanto, Hartono Guntur.2020. Analisis Dampak Infrastruktur Terhadap Pertumbuhan Ekonomi di Kabupaten Blora.Simetris Volume 14 No 1, 2020. ISSN 2686-312X. http://jurnal.syntaxliterate.co.id/index.php/s yntax-literate/article/view.

39. Ritonga, Mariyatul Kubtiyah. 2017. Pengaruh Pembangunan InfrastrukturPendidikan Terhadap Pertumbuhan Ekonomi di Provinsi Sumatera Utara.Jurnal Education and Development STKIP Tapanuli Selatan Volume 7 No 1, $2017 . \quad$ ISSN 2527-4295. https://journal.ipts.ac.id/index.php/ED/articl e/view.

40. S Sitompul, RN Ichsan, L Nasution. 2021. The Influence of Exchange Rate, Inflation, For the Results of the Development Assets of Islamic Banks. Journal of Economics, Finance and Management Studies. Vol. 4, Issue 3 March 2021: 138-148.

41. Safira. Djohan, Sjamsu. Nurjanana. 2019. Pengaruh Pengeluaran Pemerintah Pada Bidang Infrastruktur Pendidikan dan Kesehatan Terhadap Pertumbuhan Ekonomi di Provinsi Kalimantan Timur. Jurnal Ekonomi dan Bisnis, 2019. ISSN 14111713. http://journal.feb.unmul.ac.id/index.php/for umekonomi.

42. Safitri, Intan. 2016. Pengaruh Pengeluaran Pemerintah Sektor Kesehatan, Pendidikan, dan Infrastruktur Terhadap Indeks Pembangunan Manusia di Provinsi Aceh. Jurnal Ilmiah Mahasiswa Volume 1 No 1, 2016. http://jim.unsyiah.ac.id/EKP/article/view.

43. Sembanyang, Lesta Karolina B. 2011. Analisis

KeterkaitanKetersediaanInfrastruktur dengan Pertumbuhan Ekonomi di Indonesia: Pendekatan Analisis Granger Causality.Jurnal Ekonomi dan Kebijakan Volume 4 No $1,2011$. https://journal.unnes.ac.id/nju/index.php/jeja $\mathrm{k} /$ article/view.

44. Simbolon, Antonius KAP. 2018. Analisis Kointegrasi dan Kausalitas Antara Infrastruktur Jalan, Perdagangan Barang dan Pertumbuhan Ekonomi di Negara Anggota ASEAN.QE Journal Volume 7 No 2, 2018. https://jurnal.unimed.ac.id/2012/index.php/q e/article/viewfile.

45. Sirojuzilam. Mahalli, Kasyful. 2010. Regional Pembangunan, Perencanaan dan Ekonomi. Medan: USU Press.

46. Srinivasu, B. Rao, Srinivasa. 2013. Infrastructure Development And Economic Growth: Prospects And Perspective.Journal of Business Management and Social Sciences Research Volume 2 No 1, 2013. https://www.academia.edu/24400230/Infrast ructure_Development_and_Economic_grow th_Prospects_and_Perspective.

47. Sitorus, Yosephine Magdalena. Yuliana, Lia. 2018. Penerapan Regresi Data Panel Pada Analisis Pengaruh Infrastruktur Terhadap Produktivitas Ekonomi ProvinsiProvinsi di Luar Pulau Jawa Tahun 20102014.Media Statistika, 2018. ISSN 19793693.

http://ejournal.undip.ac.id/index.php/media_ statistika.

48. Sugiarto, Tony. Subroto, Waspodo Tjipto. 2019. Pengaruh Infrastruktur TerhadapPertumbuhan Ekonomi di JawaTimur.Jurnal Pendidikan Ekonomi Volume $7 \quad$ No $\quad 1, \quad 2019$. https://jurnalmahasiswa.unesa.ac.id/index.p hp/jupe/article/view.

49. Sumadiasa, I Ketut.Tisnawati, Ni Made dan Wirathi, I GAP. 2016. Pengaruh Pembangunan Infrastruktur Jalan, Listrik dan PMA Terhadap Pertumbuhan PDRB Provinsi Bali Tahun 1993-2014.E-Jurnal EP Unud Volume 5 No 7, 2016. ISSN 23020178.https://media.neliti.com/media/publica tions/165225-ID-analisis-pengaruhpembangunan-infrastruk.pdf.

50. Sunan, Muammil. 2015. Ekonomi Pembangunan. Jakarta: Mitra Wacana Media.

51. Suparno, Heri. 2014. Pengaruh Pengeluaran Pemerintah Sektor Pendidikan, Kesehatan, dan Infrastuktur Terhadap Pertumbuhan Ekonomi dan Peningkatan Pembangunan Manusia di Provinsi Kalimantan TimurEkonomika Bisnis Volume 5 No1, 2014.http://ejournal.umm.ac.id/index.php/ji be/article/view/jekobisnis.

52. Suripto dan Lestari, Eva Dwi. 2019. Pengaruh Pembangunan Infrastruktur Terhadap PDRB di Provinsi Indonesia. Wahana Jurnal Ekonomi Volume 21 No1, 2019. 
http://jurnalwahana.aaykpn.ac.id/index.php/ wahana/article/view.

53. Suryani dan Hendrayadi. 2015. Metode Riset Kuantitatif. Kencana: Jakarta.

54. Suswita, Intan. Damanik, Darwin. Panjaitan, Pawer Darasa. 2020. Pengaruh Infrastruktur Terhadap Pertumbuhan Ekonomi di Kabupaten Simalungun.Jurnal Ekonomi Pembangunan Volume 2 No 1, 2020. ISSN 2614-7181.

https://media.neliti.com/media/publications/ 327976-pengaruh-infrastruktur-terhadappertumbu-0ea72b10.pdf

55. Tapparan, Samuel Randy. 2020. Analisis Korelasi Infrastruktur Jalan TerhadapPertumbuhan Ekonomi Kabupaten Tana Toraja.Jurnal Ekonomika Volume 4 No 1, 2020. ISSN 2088-9003. http://journal.lldikti9.id/Ekonomika/article/v iew.

56. Tarmizi, Hasan Basri. 2013.Pertumbuhan Ekonomi dan Implikasinya. Medan: USU Press.

57. Todaro, Michael P dan Smith, Stephen C. 2011. Pembangunan Ekonomi Jilid 1 Edisi 11. Jakarta: Penerbit Erlangga.
58. Wardhana, Adhitya. Kharisma, Bayu dan Hanifah, Hani. 2020. Infrastruktur dan Pertumbuhan Ekonomi Kabupaten dan Kota Jawa Barat.E-Jurnal Ekonomi dan Bisnis Universitas Udayana. ISSN 2337-3067. https://ojs.unud.ac.id/index.php/EEB/article/ view.

59. Warsilan dan Noor, Akhmad. 2015. Peranan Infrastruktur Terhadap PertumbuhanEkonomi dan Implikasi pada Kebijakan Pembangunan di Kota Samarinda.Mimbar Jurnal Sosial dan Pembangunan Volume 31 No 2, 2015. ISSN 0215-

8175.https://ejournal.unisba.ac.id/index.php/ mimbar/article/view.

60. World Economic Forum. 2019. The Global Competitiveness Report 2019. http://www3.weforum.org/docs/WEF_TheG lobalCompetitivenessReport2019pdf.

How to cite this article: Sinaga S, Irsad, Rahmanta. Analysis of the influence of infrastructure on economic growth in North Sumatra Province. International Journal of Research and Review. 2021; 8(4): 196-210. DOI: https://doi.org/10.52403/ijrr.20210427 